The Polish Journal of the Arts and Culture. New Series 11

(1/2020): 93-111 [ARTYKUE]

DOI: $10.4467 / 24506249$ PJ.20.004.12990

\title{
Przygody demona Asmodeusza i króla Salomona według Talmudu babilońskiego (Gittin 68a-b). Przekład i komentarz z perspektywy projektu Elyonim veTachtonim
}

\author{
Wojciech Kosior
}

\begin{abstract}
Streszczenie
Traktat Gittin 68a-b zawiera unikatową w skali wczesnej literatury rabinicznej opowieść o przygodach króla Salomona i demona Asmodeusza. Oto król Salomon pragnie zbudować świątynię jerozolimską, ale potrzebuje do tego wsparcia Asmodeusza. Ten pomaga królowi, jednak cena, którą Salomon musi za to zapłacić okazuje się bardzo wysoka i w rezultacie już przez resztę swoich dni król śpi w otoczeniu uzbrojonej służby w obawie przed powrotem demona. Opowieść ta mimo swojej złożoności i bogactwa treściowego jak dotąd nie doczekała się tłumaczenia na język polski, a ze względu na barwność przedstawionych tam postaci, doskonale nadaje się ona do egzemplifikacji niuansów świata istot nadprzyrodzonych. Niniejsze studium ma więc dwa podstawowe cele: (1) prezentację przekładu opowieści o Salomonie i Asmodeuszu obecnej w Gittin 68a-b oraz (2) analizę rzeczonego ustępu przy użyciu kategorii wypracowanych w ramach projektu Elyonim veTachtonim, zmierzającego do utworzenia kompletnej bazy istot nadprzyrodzonych występujących we wczesnej literaturze rabinicznej.
\end{abstract}

Słowa kluczowe: Talmud babiloński, demonologia, Asmodeusz, Salomon

Wojciech Kosıor absolwent psychologii, religioznawstwa i studiów żydowskich, adiunkt w Katedrze Porównawczych Studiów Cywilizacji na Uniwersytecie Jagiellońskim. Zajmuje się Biblią hebrajską oraz wczesną literaturą rabiniczną a jego zainteresowania badawcze obejmują demonologię i angelologię żydowską. Obecnie pracuje nad elektronicznym inwentarzem istot nadprzyrodzonych Elyonim veTachtonim (https://elyonimvetachtonim.project.uj.edu.pl/).

E-MAIL:wojciech.kosior@uj.edu.pl 
Ten artykuł powstał $\mathrm{w}$ ramach projektu Istoty nadprzyrodzone oraz ich relacje z ludźmi wedtug Talmudu babilońskiego $z$ perspektywy ilościowej i jakościowej finansowanego przez Narodowe Centrum Nauki (Nr rej.: 2018/31/D/HS1/o0513).

\section{Cele i metoda}

Niniejsze studium ma dwa podstawowe cele: po pierwsze, prezentację przekładu opowieści o Salomonie i Asmodeuszu znajdującej się w talmudycznym traktacie Gittin 68a-b oraz, po drugie, analizę rzeczonego ustępu pod kątem niuansów świata istot nadprzyrodzonych Talmudu babilońskiego [dalej: TB]. Analiza ta zostanie przeprowadzona przy użyciu kategorii wypracowanych w ramach projektu Elyonim veTachtonim [dalej: EvT], który ma na celu konstrukcję kompletnej bazy elektronicznej istot nadprzyrodzonych obecnych we wczesnej literaturze rabinicznej oraz ich szczegółowy opis i klasyfikację (Kosior 2017, zob. również Elyonim veTachtonim b.d.).

Opracowanie niniejszego przekładu było motywowane dwoma czynnikami. Po pierwsze, ustęp w Gittin $68 \mathrm{a}-\mathrm{b}$ to jedna $\mathrm{z}$ nielicznych tak rozbudowanych a równocześnie tak spójnych narracji o istotach nadprzyrodzonych w TB. Istnieją co prawda obszerne fragmenty przedstawiające dyskusje rabinów na ten temat (np. Berachot 6a, Chagiga 16a czy monumentalny Pesachim 110b-112b), ale opowiadań rabinicznych i biblijnych jest niewiele i w całym korpusie tylko opowieść o perypetiach szatana i Hioba w Bawa batra 15b-16a może się mierzyć pod względem objętości z treścią ustępu w Gittin 68a-b. Narracja ta doskonale nadaje się więc do egzemplifikacji problemów świata istot nadprzyrodzonych w TB, ponieważ uwzględnia takie kwestie jak właściwości fizyczne i psychiczne poszczególnych istot, ich habitat czy skomplikowane relacje z ludźmi. Po drugie, pomimo że jest to jedyny przypadek tak rozbudowanej narracji o Asmodeuszu w skali wczesnej literatury rabinicznej, nie doczekał się on do tej pory swojego krytycznego tłumaczenia na język polski ${ }^{1}$. Te dwa czynniki decydują o charakterze niniejszego przekładu, który był pisany z myślą o jak najszerszej grupie odbiorców, chcących zapoznać się z tematem angelologii i demonologii rabinicznej.

1 W obiegu są tylko popularyzatorskie parafrazy rzeczonej opowieści, np. Agady talmudyczne: ludowe opowieści, baśnie, legendy, przypowieści, aforyzmy i przystowia wybrane $z$ Talmudu (Friedman 2005, 72-76). 


\section{Treść i bohaterowie}

Opowieść w Gittin 68a-b² przedstawia się następująco. Oto król Salomon pragnie zbudować świątynię jerozolimską. Potrzebuje jednak do tego sposobu na należytą obróbkę kamieni. Od swoich mędrców dowiaduje się o istnieniu szamira, swoistego „kornika” zdolnego do drążenia skały. Problemem jest jednak zdobycie owego szamira. Salomonowi udaje się schwytać parę demonów, którzy wyjawiają, że pomóc mu może Asmodeusz, król wszystkich demonów. Salomon wysyła więc Benajasza, swojego zaufanego żołnierza, któremu udaje się przechytrzyć Asmodeusza i sprowadzić go na dwór królewski. Demon zdradza Salomonowi lokalizację szamira: ma go anielski książę morza, który okazjonalnie pozwala z niego korzystać pewnemu dzięciołowi. Salomon wysyła Benajasza ponownie a ten posługując się podstępem zdobywa szamira i umożliwia w ten sposób budowę świątyni. Historia się jednak na tym nie kończy: gdy świątynia już stoi, Salomon wdaje się $\mathrm{w}$ dyskusję z Asmodeuszem na temat hierarchii ludzi i istot nadprzyrodzonych i ostatecznie ulega podstępowi demona, który przepędza króla a sam podszywa się pod niego. Początkowo nierozpoznanemu królowi udaje się w końcu odzyskać dawną władzę, jednak już do końca życia lęka się powrotu Asmodeusza i śpi w otoczeniu uzbrojonej służby.

Bohaterowie tej opowieści dzielą się na dwie grupy, ludzi oraz istoty nadprzyrodzone. Głównym protagonistą ludzkim jest oczywiście król Salomon (hebr. Szlomo), jedna z postaci biblijnych będąca osią narracji 2 Księgi Samuela, 1 Księgi Kronik i 1 Księgi Królewskiej. Biblia umieszcza Salomona w X w. p.n.e. jako ostatniego władcę zjednoczonego królestwa w szczytowym okresie przed rozpadem na Izrael i Judeę. Salomon prezentuje się jako niemal wzorowy król: bogaty i silny (np. $1 \mathrm{Krl}$ 10:14) a przy tym mądry (np. $1 \mathrm{Krl}$ 3:315, $1 \mathrm{Krl}$ 3:16-28) ${ }^{3}$. Równocześnie autorzy biblijni przypisują Salomonowi

2 Traktat Gittin należy do porządku Naszim, czyli do sfery halachicznych rozważań nad złożonymi relacjami małżeńskimi i dotyczy przede wszystkim prawnych aspektów rozwodów (hebr. get). Warto w tym kontekście nadmienić, iż znaleziska archeologiczne w Imperium Sasanidów z okresu formowania się Talmudu dowodzą, że dokumenty rozwodowe bywały stosowane również jako artefakty apotropaiczne mające na celu odesłanie uporczywych demonów (Frim, 2015, 196-202). Klasycznym dziełem podejmującym ten temat jest Aramaic Incantation Texts from Nippur (Montgomery 1913, 49, 76-79).

3 Tradycja biblijna przypisuje Salomonowi również autorstwo Księgi Koheleta, Pieśni nad Pieśniami, Księgi Przystów, Psalmów 72127 oraz Księgi Mądrości Salomona obecnej w kanonie katolickim. Salomon jest także tradycyjnie uznawany za autora lub też jest jednym z głównych bohaterów licznych dzieł apokryficznych i pseudepigraficznych, takich jak np. Ody 
słabość do kobiet i gotowość do czczenia innych niż Jahwe bogów, co zresztą ostatecznie zostaje mu poczytane za grzech i za co zostaje ukarany rozpadem swojego królestwa (np. $1 \mathrm{Krl} \mathrm{11).}$

Bezpośrednio z Salomonem związane są dwie inne postacie. Matką Salomona, wzmiankowaną tylko raz w Gittin 68a-b, jest Batszeba. Według Biblii to żona Uriasza Hetyty, jednego z oficerów króla Dawida. Pewnego razu Dawid dostrzega Batszebę podczas porannej kąpieli i zauroczony jej pięknem, postanawia wziąć ją sobie za żonę i podstępem doprowadza do śmierci Uriasza (2 Sm 11). Ostatecznie Batszeba przeżywa króla Dawida i zostaje królowąmatką. Z kolei Benajasz syn Jojady pełni w Gittin $68 \mathrm{a}-\mathrm{b}$ rolę wiernego sługi króla Salomona. To żołnierz należący jeszcze do sił specjalnych Dawida (2 Sm 23:8-38; 1 Krn 11:10-47) a po jego śmierci, służący Salomonowi jako jeden z najważniejszych oficerów (np. $1 \mathrm{Krl} 2: 25 ; 2: 34 ; 2: 46$ ). Oprócz tych trzech postaci ludzkich wskazać można jeszcze kilku innych, mniej wyrazistych bohaterów pojedynczych i zbiorowych: mędrców-doradców Salomona, żony i nałożnice króla, czy wreszcie różnych anonimowych mieszkańców Jerozolimy: ślepca i niegodziwca, parę nowożeńców, szewca i jego klienta czy wreszcie ubogą wdowę.

Drugą grupą bohaterów są istoty nadprzyrodzone a kluczową dla rozwoju niniejszej narracji postacią jest szamir4 . Pojawia się on w ośmiu jednostkach tekstowych w skali całego $\mathrm{TB}^{5}$ : dwa razy mówi się o stworzeniu szamira na początku świata (Pesachim 54a, Sota 48b), raz opisuje się go jako posiadającego rozmiary ziarna jęczmienia oraz zdolnego do przecinania i drążenia

Salomona, Psalmy Salomona czy wreszcie Testament Salomona. Dalekie echa popularności tradycji o królu-magu można znaleźć w dziełach powstałych na gruncie zachodniego okultyzmu, przede wszystkim w Kluczu Salomona z XIV-XV w. i Mniejszym Kluczu Salomona z XVII w., które przedstawiają podstawy goecji, tj. wzywania i kontrolowania istot nadprzyrodzonych (zob. np. Butler 2011, 48-52).

4 Istnieją dwie podstawowe grupy interpretacji terminu szamir. Według pierwszej, szamir jest rodzajem szczególnie twardego kamienia wykorzystywanego do cięcia, szlifowania i polerowania innych materiałów (Jastrow 1903, 1596). Druga grupa interpretacji, popularna wśród tradycyjnych rabinów takich jak Raszi (ad Pesachim 54a) czy Rambam (ad PirkeAwot 5:6), traktuje termin szamir jako nazwę żywego stworzenia, robaka zdolnego do wiercenia tuneli w litej skale (Melamed 2005, 499). W niniejszym studium przyjęto tę drugą interpretację zgodnie z podstawowymi założeniami projektu EvT, mówiącymi m.in. że lepiej omyłkowo uwzględnić $\mathrm{w}$ bazie jakiś termin niż zignorować potencjalną istotę nadprzyrodzoną. Przeglądu znaczeń terminu szamir dokonuje E. Klein (Klein 1987, 666). W kwestii późniejszych tradycji zob. np. Shamir (Bacher i Blau b.d.)

5 W przygotowaniu konkordancji posłużono się bazą EvT w wersji 5 „Hormin” (Elyonim veTachtonim b.d.). 
każdej substancji (Sota 48b) i raz mówi się o tym, że szamir przestał istnieć wraz ze zburzeniem domu świątynnego (Sota 48a). Pozostałe pięć jednostek lokuje szamira w kontekście tradycji o zbudowaniu świątyni jerozolimskiej, z czego trzy jednostki znajdują się we fragmencie Gittin 68a-b. Oprócz tego jednostka w Sota $48 \mathrm{~b}$ dodatkowo wyjaśnia, skąd wiadomo, że to właśnie szamir został wykorzystany do budowy świątyni a Chullin 63a powtarza tradycję o dzięciole, który był odpowiedzialny za dostarczenie szamira na teren budowy.

Z szamirem bezpośrednio powiązany jest anielski książę morza (aram. sara dijama). Należy on do większej grupy istot nadprzyrodzonych tzw. książąt (hebr. sar, aram. sara oraz isra). Termin ten w zdecydowanej większości przypadków wystąpienia w TB odnosi się po prostu do zwykłych ziemskich książąt, natomiast w 28 jednostkach oznacza istotę nadprzyrodzoną: mogą być to anielscy reprezentanci poszczególnych nacji (np. Chullin 92a, Berachot 4b, Joma 77a, Makkot 12a), opiekunowie domu (Pesachim 111b), władcy zjawisk atmosferycznych takich jak grad (Pesachim 118a-b) i wysoka lub niska temperatura (Sanhedrin 108b) czy wreszcie nadzorcy określonych miejsc, np. zaświatów (Szabbat 104a, Sanhedrin 52a, Arachin 15b). Sam książę morza pojawia się w czterech jednostkach: dwukrotnie w reiteracji mitu o przejściu przez Morze Sitowia (Pesachim 118b, Arachin 15a), raz w ponownym opowiedzeniu stworzenia świata (Bawa Batra 74b), gdzie zostaje utożsamiony z biblijnym potworem Rahabem i raz w Gittin $68 \mathrm{a}-\mathrm{b}$, gdzie pełni rolę strażnika szamira.

Jakkolwiek w budowie świątyni kluczową rolę odgrywa szamir, to jednak głównym bohaterem nadprzyrodzonym Gittin 68a-b jest demon Asmodeusz (hebr. Aszmedaj) ${ }^{6}$. W całym TB pojawia się on w siedmiu jednostkach tekstowych, z czego sześć należy do prezentowanego tutaj ustępu. Oprócz tego wzmiankowany jest tylko jeden raz w Pesachim 110a jako król wszystkich demonów (hebr. szedim). Poza TB a w ramach wczesnej literatury rabinicznej Asmodeusz pojawia się jeszcze w midraszu Bamidbar rabba 11:3, który wspomina tylko, iż demon brał udział w budowie świątyni a potem próbował pozbyć się Salomona. Natomiast w szerszym kontekście judaizmu rabinicznego i wczesnego chrześcijaństwa Asmodeusz pojawia się w Księdze

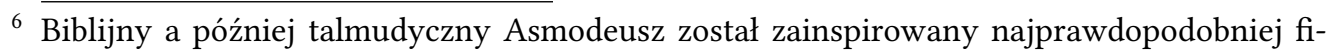
gurą Aeszma Dewa, zaratusztriańskiego demona gniewu pojawiającego się jeszcze w Aweście (m.in. Jaszt 19:46). W kwestii przeglądu interpretacji pochodzenia Asmodeusza (Hutter 1999, 106; Kohler i Ginzberg b.d.; Stave b.d.). 
Tobiasza $a^{7}$ jako złośliwy demon mordujący kolejnych mężów Sary zanim ci zdążą dokonać swojego obowiązku małżeńskiego w noc poślubną i w Testamencie Salomona, jako syn upadłego anioła, odpowiedzialny za zakłócanie pożycia intymnego małżonków i prowokowanie zdrad (TestSal 21-25). To ostatnie dzieło jest o tyle ważne, że prezentuje tradycję o budowie świątyni jerozolimskiej, do której król Salomon wykorzystuje całe zastępy istot nadprzyrodzonych a w tym demona Asmodeusza.

Wśród istot nadprzyrodzonych obecnych w Gittin 68a-b spotykamy również pewne anonimowe demony (hebr. szedim) ${ }^{8}$, niezwykłego dzięcioła opiekującego się szamirem oraz anioły zamieszkujące firmament. Jakkolwiek pełnią one poboczne role w narracji, to jednak egzemplifikują pewne bardziej ogólne prawidłowości.

\section{Technikalia}

Podstawą prezentowanego tutaj przekładu jest dziewiętnastowieczne wydanie wileńskie TB. W tłumaczeniu i komentarzu uwzględniono również innych świadków tekstu zawierających rzeczony ustęp ${ }^{9}$. Zaobserwowane niezgodności w zdecydowanej większości nie miały wpływu na interpretację treści opowieści: były to warianty ortograficzne uwzględniające matres lectionis, użycie bądź rozwinięcie skrótów w zapisie czy zakres cytowania ustępów biblijnych. W przekładzie odnotowano tylko te różnice, które miały bezpośredni związek z głównymi tematami analizowanego ustępu takie jak np. dobór kluczowych słów czy glosy wyjaśniające wprowadzone przez skrybę.

7 Dzieło to ma różny status w poszczególnych tradycjach religijnych i denominacjach. Jest to tzw. księga zewnętrzna w judaizmie rabinicznym, apokryf w chrześcijaństwie protestanckim i księga deuterokanoniczna w chrześcijaństwie katolickim. Fakt, iż fragmenty tej księgi znaleziono wśród zwojów znad Morza Martwego pozwala podejrzewać, że była ona znana także w środowisku wczesnych rabinów.

8 Termin „demon” traktuje się w niniejszym studium tak jak w projekcie EvT czyli jako kategorię zewnętrzną (etic) oznaczającą grupę istot nadprzyrodzonych, obejmującą oprócz szedim również takie typy jak mazikim (pol. „szkodniki”) czy ruchot (pol. „dusze”). Wykorzystanie tego terminu w poniżej zaprezentowanym przekładzie opiera się na metonimii „nazwa klasy zamiast nazwy egzemplarza" (zob. Kosior 2017, 95-97).

9 Warianty porównano ze sobą za pomocą platformy elektronicznej Hachi Garsinan udostępnionej przez The Friedberg Jewish Manuscript Society (The Friedberg Jewish Manuscript Society b.d.). 
Tekst niniejszej opowieści bazuje na orzeczeniach i sufiksach osobowych, natomiast bardzo często pomija podmioty i dopełnienia, co zresztą jest charakterystyczne dla języka TB. Sprawia to, że wiele treści trzeba wywnioskować samodzielnie, dopasowując tekst do schematów narracyjnych oraz w dużym stopniu polegać na istniejących tradycjach komentatorskich i tłumaczeniowych. Przygotowując niniejszy przekład pod uwagę wzięto zatem angielskie wydania The Soncino Talmud, Rodkinson Talmud oraz William Davidson Talmud $^{10}$. Treści „dodane” do tekstu oryginalnego zaznaczono przez umieszczenie ich w nawiasach kwadratowych. Dzięki temu Czytelnicy będą mogli już na pierwszy rzut oka zorientować się, jak wiele trzeba było „dopowiedzieć" do źródła, by stało się ono w ogóle zrozumiałe. Tekst oryginalny nie dysponuje też rozróżnieniem na majuskułę i minuskułę, nie zawiera znaków interpunkcyjnych a partycję tekstu przeprowadza w stopniu minimalnym. Podział na poszczególne zdania i akapity został więc wprowadzony na etapie tłumaczenia ${ }^{11}$.

W ustępie Gittin 68a-b sporadycznie pojawiają się cytaty biblijne zawierające gry słów i wieloznaczności, które trudno oddać powołując się na już istniejące polskie przekłady Biblii hebrajskiej [dalej: BH]. Z tego względu posłużono się własnym tłumaczeniem, wyróżnionym w tekście kursywą, za podstawę przyjmując czwarte wydanie Biblia Hebraica Stuttgartensia znajdujące się w pakiecie BibleWorks 10 (Elliger i Rudolph 1977). W miejscach, gdzie było to konieczne dla zrozumienia kontekstu, rozwinięto cytaty biblijne, co zgodnie ze stosowaną konwencją graficzną, zaznaczono nawiasami kwadratowymi.

\footnotetext{
${ }^{10}$ To ostatnie wydanie uwzględnia komentarze późniejszych rabinów już w tekście głównym.

${ }^{11}$ Organizując treść przekładu zdecydowano się na jedną roszadę. W wydaniu wileńskim oraz we wszystkich wariantach udostępnionych przez Hachi Garsinan bezpośrednio po fragmencie opisującym podróż Benajasza i Asmodeusza do Jerozolimy następuje fragment oczekiwania na spotkania z królem, natomiast rozmowa Benajasza i Asmodeusza obecna jest po epizodzie przechwycenia szamira. $Z$ treści tej rozmowy wynika jednak, że ma ona miejsce zaraz po podróży do Jerozolimy i dla ułatwienia lektury zdecydowano się ją przesunąć.
} 


\section{Przekład Gittin 68a-b}

[Napisano, iż król Salomon rzekł:] [zgromadziłem srebro, złoto i klejnoty wszelkich królestw], zapewnitem ${ }^{12}$ sobie śpiewaków i śpiewaczki, rozkosze ludzkie: bogaty harem ${ }^{13}$ (Koh 2:8). [Terminy] śpiewaków i śpiewaczki [oznaczają dwa] rodzaje instrumentów [muzycznych], zaś rozkosze ludzkie to „sadzawki i łaźnie”. [Natomiast frazę] bogaty harem zwykliśmy [w Babilonii] tłumaczyć jako „demony oraz demonice”. [Tymczasem rabini z] Palestyny twierdzą, że [terminy te oznaczają w stosowanym przez nich dialekcie języka aramejskiego] „zaprzęgi”, [mimo że] rabbi Jochanan, [tannaita pochodzący z Palestyny], powiedział: w [mieście] Szichin ${ }^{14}$ [w Galilei] mieszkało 300 rodzajów demonów, ale nie wiem kim jest owa demonica [z Księgi Koheleta]. Mar powiedział: [w Babilonii] tłumaczymy to jako „demony oraz demonice”.

A po co [Salomonowi] były te demony i demonice? [Odpowiedź na to pytanie znajduje się] w słowach [Biblii]: świątynię zbudowano $z$ gotowego $k_{\text {kamienia }}^{15}$ [i dlatego podczas budowy nikt $w$ domu nie styszat ani mtota ani siekiery ani innego narzędzia z żelaza] (1 Krl 6:7). [Król Salomon] zapytał

${ }^{12}$ Hebr. asiti, dosł. „zrobiłem”, „uczyniłem”.

${ }^{13}$ Hebr. szidda wesziddot. Nawet pobieżny przegląd tłumaczeń na współczesne języki pokazuje, że nie ma zgody co do znaczenia tej frazy. Istnieją trzy podstawowe kierunki interpretacji tejże: „konkubiny” (np. Biblia Tysiąclecia, English Standard Version, New International Version), „instrumenty muzyczne” (np. Biblia Gdańska, King James Bible, American Standard Version), „podczaszy” tudzież „służący” (np. Biblia Jakuba Wujka, Douay-Rheims Bible, Brenton Septuagint Translation). Klasyczne słowniki hebrajszczyzny biblijnej stwierdzają, że znaczenie terminu jest „niepewne” (Brown, Driver, Briggs i in. 1907, 9713; Harris, Archer i Waltke 1980, 2332b; Holladay 2000, 8414). Istnieje jednak tendencja do rozpoznania w tej frazie meryzmu oznaczającego „harem”, co prawdopodobnie jest motywowane z jednej strony paralelizmem z frazą wetaanugot bnej adam, $\mathrm{tj}$. „i rozkosze ludzkie” a z drugiej tradycją o rozwiązłości seksualnej króla Salomona - i ten właśnie kierunek przyjęto w proponowanym tutaj tłumaczeniu (contra: Friedländer 1889, 368).

${ }^{14}$ Miasto w Galilei, a więc w rodzinnych stronach rabbiego Jochanana. Znane było również jako Asochis w pismach Józefa Flawiusza (Starożytności 13:337; Wojny żydowskie 1:86) i słynęło z przemysłu garncarskiego. Według tradycji przekazanej w Talmudzie jerozolimskim (Taanit 4:5 24b) miasto upadło, ponieważ praktykowano tam magię (hebr. keszafim). M. Avi-Yonah, Shihin, s. 476. Alternatywnie można więc ten fragment zinterpretować jako żart mający na celu ośmieszenie mieszkańców miasta. Manuskrypt Vatican 130 ma: „Salomon miał trzysta rodzajów demonów w Szichin - nie wiem jednak, kim jest sama demonica." Glosa na marginesie manuskryptu dodaje: „tj. jak wygląda [owa demonica] i jaką ma naturę albo czy sprawuje władzę nad wszystkimi [demonami]". We wszystkich wariantach opinia rabbiego Jochanana przytoczona jest w języku hebrajskim misznaickim.

${ }^{15}$ Hebr. ewen szlema, co daje grę słów z hebrajskim imieniem Salomona, tj. Szlomo. 
mędrców: jak mam pracować, [żeby zbudować świątynię w ten sposób]? Ci odpowiedzieli mu: istnieje [takie stworzenie jak] szamir [i nie ma takiej rzeczy, której nie mógłby on przeciąć i wyszlifować. W zamierzchłych czasach] Mojżesz użył go [do obróbki] kamieni [znajdujących się na] efodzie [arcykapłana sprawującego kult w namiocie spotkania]. Salomon zapytał ich: gdzie można znaleźć [tego szamira]? Odpowiedzieli mu: przyprowadź demona oraz demonicę i zwiąż ich. Być może [to wiedzą] i ci ujawnią.

[Salomon] sprowadził więc sobie demona oraz demonicę i związał ich. Ci jednak odparli mu: nie wiemy, [gdzie znaleźć szamira] - ale może Asmodeusz, król demonów to wie? [Salomon] zapytał: gdzie mogę znaleźć [Asmodeusza]? Demony odparły mu: na pewnej górze ${ }^{16}$. Wykopał tam sobie studnię, wypełnił ją wodą, przykrył skałą i zabezpieczył swoją pieczęcią ${ }^{17}$. Każdego dnia wznosi się na sklepienie i studiuje w niebiańskiej uczelni ${ }^{18}$, po czym zstępuje na ziemię i studiuje w ziemskiej uczelni. Potem [wraca] i sprawdza swoją pieczęć, [by upewnić się, że nikt nie próbował dobrać się do jego studni]. Następnie [łamie ją], pije ze studni, po czym znowu ją przykrywa, pieczętuje i odchodzi.

[Salomon] posłał po Benajasza syna Jojady i dał mu łańcuch oraz pierścień, na których było wyryte [boskie] imię ${ }^{19}$. [Dał mu też] wełniane runo oraz bukłaki z winem. [Benajasz udał się na tę górę] i wykopał studnię poniżej [studni Asmodeusza. W ten sposób] spuścił wodę [ze studni Asmodeusza a potem] uszczelnił ją wełnianym runem. [Następnie udał się] powyżej [studni Asmodeusza] i wykopał kolejną, do której nalał wina, [dzięki czemu dostało się ono do studni Asmodeusza. Pieczęć demona natomiast pozostała nienaruszona. Benajasz] zasypał [obie studnie, które wykopał], po czym wdrapał się na drzewo [i tam oczekiwał nadejścia demona]. Gdy [Asmodeusz wreszcie] nadszedł, sprawdził swoją pieczęć, [złamał ją,] odsłonił studnię i znalazł tam wino ${ }^{20}$. Rzekł do siebie: wszak napisano: wino jest szyderca a trunek jest

${ }^{16}$ Manuskrypt Arras 889 ma: „w pewnym miejscu”.

${ }^{17}$ Aram. guszpanka. Co ciekawe, ten sam termin pojawia się w dłuższym ustępie demonologicznym w Berachot 6a na określenie pieczęci służącej do zabezpieczenia prochu wykorzystanego wcześniej do wykrycia śladów kogucich łap (aram. karej detarngola) demona. Uwaga ta jest ważna, ponieważ w dalszej części tej opowieści nogi demona Asmodeusza są szczególnym przedmiotem zainteresowania rabinów.

${ }^{18}$ Aram. metiwta to odpowiednik hebr. jesziwa, czyli uczelni rabinicznej.

${ }^{19}$ Manuskrypty Arras 889 i Vatican 130 określają to imię wprost jako hebr. szem hameforasz, dosł. „wytłumaczone imię” czyli boskie imię zapisane we właściwy mu sposób.

${ }^{20}$ Można się zastanawiać, czy swoista „przemiana” wody w wino nie jest jakąś aluzją do nowotestamentowego mitu o weselu w Kanie Galilejskiej (J 2:1-11). 
hałaśliwy - nikt, kto przez nie błądzi, nie jest mądry (Prz 20:1) oraz: nierządnice, wino i moszcz odbieraja rozum $\left(\mathrm{Oz}_{4}: 11\right)$ - w takim razie nie będę tego pić. Gdy jednak poczuł pragnienie, nie potrafił sobie odmówić [wina], więc napił się go, [i natychmiast] odurzył się i zapadł w sen. [Tymczasem Benajasz] zszedł z drzewa i spętał Asmodeusza łańcuchem [z wygrawerowanym bożym imieniem] a ten zaraz po przebudzeniu [bezskutecznie] próbował się wyswobodzić. [Wtedy Benajasz] krzyknął: masz na sobie imię twojego pana, masz na sobie imię twojego pana!

[Benajasz] zabrał [Asmodeusza do Jerozolimy]. Gdy przechodzili obok jakiejś palmy, [Asmodeusz] otarł się o nią, a [drzewo] się wywróciło. Gdy przechodzili obok jakiegoś domu, [Asmodeusz] zburzył go ${ }^{21}$. Gdy przechodzili obok jakiejś chatki należącej do pewnej wdowy, [owa wdowa] wyszła i błagała go, [by nie zniszczył jej dobytku] a [Asmodeusz] wygiął się [tak bardzo, że] złamał sobie kość. Rzekł: oto jest, jak napisano: łagodnym głosem można łamać kości (Prz 25:15).[Poszli dalej. Gdy Asmodeusz] ujrzał ślepca, który zabłądził, pomógł mu znaleźć drogę. [Gdy później] ujrzał pijaka, który zabłądził, [również] jemu pomógł znaleźć drogę. [Później mijali trwającą ceremonię ślubną. Gdy Asmodeusz] ujrzał, jak radują się [nowożeńcy], zapłakał. [Następnie mijali zakład szewski. Gdy] usłyszał mężczyznę mówiącego do szewca: zrób mi takie buty, by wytrzymały siedem lat, roześmiał się. [Wreszcie mijali] maga odprawiającego czary. [Gdy Asmodeusz] go usłyszał, roześmiał się [znowu].

Benajasz zapytał: $\mathrm{z}$ jakiego powodu pomogłeś tamtemu ślepcowi odnaleźć drogę? [Asmodeusz] odparł: [aniołowie] na sklepieniu niebieskim ${ }^{22}$ mówią o nim, że to człowiek sprawiedliwy i bez skazy i że każdy, kto mu pomoże, zapewni sobie udział w przyszłym świecie. Benajasz zapytał znowu:] a z jakiego powodu pomogłeś odnaleźć drogę tamtemu pijakowi? [Asmodeusz] odrzekł: [aniołowie] na sklepieniu niebieskim mówią o nim, że ten człowiek jest skończonym niegodziwcem. Pomogłem mu, żeby mógł [kontynuować swoje niecne sprawki] na tym świecie [i w ten sposób, żeby nie zasłużył sobie na udział w przyszłym świecie. Benajasz zapytał ponownie:] a z jakiego powodu zapłakałeś, gdy ujrzałeś radość [nowożeńców? Asmodeusz] odrzekł: [pan młody] umrze w ciągu trzydziestu dni. [Jego żona] natomiast

${ }^{21}$ Te wydarzenia można zinterpretować jako grę słów ze zhebraizowanym imieniem Asmodeusza (Aszmedaj), które zawiera w sobie litery szin, mem, dalet będące podstawą hebrajskiego rdzenia oznaczającego „niszczyć”.

${ }^{22}$ Aram. berakija. O obecności aniołów w tym fragmencie wnioskuje się na bazie metonimii „miejsce zamieszkania zamiast mieszkańca”. 
będzie musiała zaczekać [z ponownym ożenkiem] do czasu, aż brat jej męża osiągnie pełnoletniość [i będzie mógł ją wyzwolić z lewiratu, co z kolei pozwoli jej ponownie wyjść za mąż ${ }^{23}$. Benajasz zapytał:] a $z$ jakiego powodu roześmiałeś się, słysząc mężczyznę proszącego szewca o buty, które wytrzymają siedem lat? [Asmodeusz] odpowiedział: [wiem, że ten] mężczyzna nie przeżyje siedmiu dni, więc po co mu [takie dobre] buty? [Benajasz zapytał:] a z jakiego powodu roześmiałeś się, gdy ujrzałeś maga odprawiającego czary? [Asmodeusz] odparł: ów mag siedział na królewskim skarbcu [ukrytym pod ziemią] i nawet jego magia nie pozwoliła mu rozpoznać, co znajduje się pod nim.

Gdy dotarli ${ }^{24}$ [do Jerozolimy, Asmodeusz] musiał zaczekać trzy dni, zanim został przyprowadzony przed oblicze Salomona. Pierwszego dnia zapytał [służących]: dlaczego król nie chce mnie widzieć? Odrzekli mu: wypił za dużo i zaniemógł. [Asmodeusz] wziął jedną cegłę i położył ją na drugiej. Gdy doniesiono o tym Salomonowi, ten rzekł: [Asmodeusz] powiedział wam [w ten sposób], żebyście dali mi wypić [klina]. Drugiego dnia Asmodeusz zapytał: dlaczego król nadal nie chce mnie widzieć? [Służący] odrzekli mu: zjadł za dużo i zaniemógł. [Asmodeusz] zdjął cegłę którą wcześniej położył na drugiej. Gdy doniesiono o tym Salomonowi, ten rzekł: [Asmodeusz] powiedział wam [w ten sposób], żebyście zabrali mi jedzenie.

Pod koniec trzeciego dnia ${ }^{25}$ przyprowadzono [Asmodeusza] przed oblicze [Salomona. Demon] wziął trzcinę, odmierzył nią cztery łokcie i rzucił ją przed [króla] mówiąc: spójrz - gdy człowiek ${ }^{26}$ umrze, nie pozostanie mu nic innego niż te cztery łokcie jego grobu. Ty zawładnąłeś całym światem i nie będziesz mieć dość, dopóki nie zawładniesz również mną. [Salomon] odparł: niczego od ciebie nie chcę. Pragnę tylko zbudować świątynię jerozolimską a do tego potrzebuję szamira. [Asmodeusz] rzekł: to nie mi dano [władzę nad szamirem], ale księciu morza a on przekazuje ją tylko pewnemu

\footnotetext{
${ }^{23}$ Lewirat oznacza rodzaj małżeństwa: jest to konieczność poślubienia wdowy przez brata zmarłego męża i spłodzenia z nią potomstwa, które otrzyma imię denata. Brat zmarłego, o ile tylko osiągnie pełnoletniość, tj. skończy trzynasty rok życia, może jednak odmówić ślubu, co z kolei pozwala wdowie na przeprowadzenie rytuału chalica i w ten sposób ponowne wyjście za mąż za kogoś innego (Satlow 2018, 187-189).

${ }^{24}$ Aram. meta, dosł. „dotarł”.

${ }^{25}$ Wydanie weneckie (28o-283) i Soncino (244-249) oraz manuskrypty Arras 889 i Munich 95 mają „na początku trzeciego dnia”.

${ }^{26}$ Aram. hahu giwra, dosł. „pewien człowiek”, czyli prawdopodobnie eufemizm na króla Salomona.
} 
dzięciołowi ${ }^{27}$, który złożył przysięgę [sprawowania należytej pieczy nad robakiem] ${ }^{28}$. A co [ów dzięcioł] robi z szamirem? Niesie go w góry, które nie nadają się do zamieszkania i kładzie na skale [a szamir wierci w niej otwory tak, że skała] pęka. Następnie [dzięcioł] znosi tam nasiona drzew i sypie je [do szczelin] w skale. [Drzewa wyrastają ze skał i dzięki temu wcześniej niedostępne góry] stają się zdatne do zamieszkania. $\mathrm{Z}$ tego powodu nazywamy [dzięcioła] tnącym skały ${ }^{29}$.

[Król wysłał Benajasza na poszukiwania. Benajasz] znalazł gniazdo dzięcioła, w którym były jego młode i przykrył je [kopułą z] przezroczystego szkła. Gdy dzięcioł przyleciał, chciał wejść do gniazda, ale nie mógł tego zrobić, więc [odleciał i po chwili] powrócił z szamirem, którego umieścił na górze szklanej kopuły. [Benajasz] rzucił [kamykiem, by przestraszyć dzięcioła, a ten] upuścił [szamira]. [Sługa przechwycił robaka, a dzięcioł popełnił samobójstwo przez] uduszenie, ponieważ [nie dotrzymał] przysięgi [strzeżenia szamira].

[Salomon] zatrzymał przy sobie [Asmodeusza] do czasu, aż skończył budowę świątyni jerozolimskiej ${ }^{30}$. Pewnego dnia, [gdy zostali] sam na sam, [Salomon] powiedział mu: napisano: [bóg, który wyprowadzit [Hebrajczyków] $z$ Egiptu jest] jak rogi bawotu [- pożre narody, które go uciskaja, zmiażḋy ich kości i razi swoimi strzałami] (Lb 24:8). Naucza się, że [fraza] jak rogi oznacza aniołów posługi a [słowo] bawołu oznacza demony. Pod jakim względem jesteś więc lepszy on nas, [ludzi - czyli od tych, których Biblia opisuje jako narody? Asmodeusz] odrzekł: zdejmij ze mnie łańcuch i daj mi twój pierścień a wtedy udowodnię ci moją wyższość. Salomon zdjął więc łańcuch [z Asmodeusza] i dał mu swój pierścień. [Wtem] Asmodeusz połknął [Salomona $]^{31}$, oparł jedno skrzydło na ziemi a drugie na sklepieniu niebieskim

${ }^{27}$ Aram. tarngola bara, dosł. „dziki kogut”. Według Chullin 63a tym ptakiem, który przynosi szamira na teren budowy świątyni jest dukifat wzmiankowany m.in. w Kpł 11:19 a na ogół tłumaczony jako „dzięcioł”. Zob. przypis nr 29.

${ }^{28}$ Manuskrypt Vatican 130 zawiera kilka glos do tego ustępu: dzięcioł pilnuje, by zwrócić szamira księciu morza, gdy nie jest mu już potrzebny, tzn. gdy zbuduje sobie w górach gniazdo i gdy teren zostanie na tyle wypełniony roślinnością, by dzięcioł i jego dzieci miały co jeść.

${ }^{29}$ Aram. nagar tura. Termin ten pojawia się w miejsce hebr. dukifat w Targumie PseudoJonatana oraz Targumie Onkelosa do Kpł 11:19.

${ }^{30}$ Manuskrypty Arras 889 i Vatican 130 dodają: „do końca [okresu] panowania Salomona”.

${ }^{31}$ Aram. baelejah, dosł. „połknął go”, co może się odnosić do Salomona, ale już nie do „pierścienia”, który jest rodzaju żeńskiego (aram. izka). Contra: Raszi ad loc. 
i zwymiotował go $^{32}$ na odległość czterystu parasangów ${ }^{33}$. [Gdy] Salomon [znalazł się z dala od swojego pałacu], zapytał: i jakiż pożytek ${ }^{34}$ ma człowiek $z$ całej swojej ciężkiej pracy pod stońcem? (Koh 1:3) ) $^{35}$. [Po oddaleniu Salomona, Asmodeusz podszył się pod niego i zasiadł na tronie, gdy tymczasem prawdziwy król błąkał się po kraju nierozpoznany.]

[Napisano, iż król Salomon rzekł wtedy:] $i$ oto nagroda za cała moja cięż$k a$ prace (Koh 2:10). Co znaczy [fraza] $i$ oto? Raw i rabbi Szmuel [przedstawili różne opinie $\mathrm{w}$ tej kwestii]. Jeden powiedział: [fraza $i$ oto odnosi się] do laski [którą Salomon trzymał w dłoni]. Drugi powiedział: [fraza $i$ oto odnosi się] do jego płaszcza. [Salomon] błąkał się od drzwi do drzwi i gdziekolwiek zaszedł, mówił: ja, Kohelet, byłem niegdyś królem Izraela zasiadajqcym $w$ ferozolimie (Koh 1:12), [ale nikt nie chciał mu uwierzyć. W końcu] trafił na [posiedzenie] Sanhedrynu ${ }^{36}$, a obecni tam mędrcy [ujrzawszy Salomona] orzekli: przecież człowiek niespełna rozumu nie potrafiłby tak długo powtarzać dokładnie tych samych słów ${ }^{37}$. Kim on w takim razie jest? [Mędrcy postanowili więc sprawdzić czy ktoś nie podszywa się pod Salomona. W pierwszej kolejności] zapytali Benajasza: czy król cię kiedykolwiek wzywa? [Benajasz] zaprzeczył. Następnie mędrcy wysłali zapytanie do królewskich żon [Salomona]: czy król sypia z wami? Żony odpowiedziały: owszem,

${ }^{32}$ Aram. patkejah, dosł. „wyrzucił go”.

${ }^{33} \mathrm{Ok}$. 1600-180o km. Można podejrzewać, że dystans czterystu parasangów należy interpretować symbolicznie jako oznaczający bardzo dużą odległość. Np. w traktacie Taanit 1oa o Egipcie mówi się, że ma powierzchnię 400 parasangów na 400 parasangów. W kwestii jednostek miar stosowanych w TB zob. np. The Talmud. The Steinsaltz Edition. A Reference Guide (Steinsaltz 1996, 283-284).

${ }^{34}$ Hebr. jitron. Wartość gematryczna tego terminu to 666 - czyli tyle, ile talentów złota dostarczali poddani sąsiedzi królowi Salomonowi każdego roku według $1 \mathrm{Krl}$ 10:14.

35 Wydanie weneckie (280-283) oraz Soncino (244-249) dodają jeszcze w tym miejscu werset z Koh 12:13: [oto koniec, wszystko zostało wystuchane; bój się boga i strzeż jego przykazań] bo to [los] każdego człowieka. Werset ten zasadniczo zmienia wydźwięk stwierdzenia króla Salomona. Słowa ciężkiej pracy pod słońcem należy prawdopodobnie rozumieć jako odnoszące się do epizodu konstrukcji świątyni jerozolimskiej. Posługując się tym wersetem rabini zdają się też sugerować, w jakim okresie życia króla Salomona należy lokować powstanie Księgi Koheleta.

${ }^{36}$ Sanhedryn to zgromadzenie mędrców judejskich pełniące przede wszystkim funkcje sądownicze, które doszło do znaczenia dopiero w ostatnich wiekach p.n.e. Obecność Sanhedrynu w niniejszej opowieści stanowi więc rabiniczną fikcję.

${ }^{37}$ Manuskrypt Vatican 130 ma glosę wyjaśniającą: „[człowiek niespełna rozumu nie potrafiłby tak długo powtarzać dokładnie tych samych słów] bez mówienia [przy tym] innych głupot”. 
sypia. [Mędrcy] poprosili [zatem]: sprawdźcie dokładnie jego stopy ${ }^{38}$ [- czy są to stopy zwykłego człowieka. Żony] odparły: sypia z nami nie ściągając skarpet! Chce [z nami sypiać], nawet wtedy gdy mamy okres! [Mało tego], domaga się [współżycia] nawet z Batszebą, swoją matką! [Mędrcy w ten sposób domyślili się, że ktoś podszywa się pod prawdziwego króla.] Przyprowadzili Salomona, [który dotychczas błąkał się od drzwi do drzwi] i dali mu łańcuch oraz pierścień, na których było wygrawerowane [boskie] imię. Gdy [tak wyposażony Salomon] wszedł [do sali tronowej, Asmodeusz] zobaczył go i uciekł. Mimo tego jednak, że [demon uciekł, Salomon] wciąż się go bał, jak napisano: oto toże Salomona - otacza je sześćdziesięciu najsilniejszych mężczyzn Izraela, każdy z mieczem [ $w$ dłoni], a wszyscy sa ludźmi wyćwiczonymi $w$ wojnie, [każdy] ma miecz u boku [dla ochrony] przed strachem $w$ [każda] noc (Pnp 3:7-8) ${ }^{39}$.

Raw i rabbi Szmuel [mieli różne zdania w kwestii historii króla Salomona]. Jeden powiedział: [Salomon był] najpierw królem a potem już został zwykłym człowiekiem [na resztę życia]. Drugi [natomiast] stwierdził: [Salomon] był najpierw królem, potem zwykłym człowiekiem, [ale na koniec] znów został królem [i zmarł jako król].

\section{Komentarz}

Niniejsza opowieść cechuje się dużym zróżnicowaniem istot nadprzyrodzonych w niej występujących, co z kolei pozwala na zastosowanie złożonego systemu klasyfikacyjnego ${ }^{4^{0}}$. Same istoty nadprzyrodzone można umieścić w różnych klasach - spotykamy tu demony (Asmodeusz, pewne anonimowe demony), anioły (książę morza, anioły na firmamencie) oraz potwory (szamir, niezwykły dzięcioł). Nie zaskakuje też, że te istoty posiadają liczne

${ }^{38}$ Aram. kera znaczy „kolano”, ale również „noga”. Raszi ad loc tłumaczy, że demony mają nogi jak koguty, opierając się na wzmiankowanym już ustępie demonologicznym w Berachot 6a. Oprócz tego, można się zastanawiać, czy nie jest to nawiązanie do tradycji o owłosionych nogach królowej Saby, jednej z kochanek króla Salomona - przy czym jest to dość późna tradycja i słabo poświadczona w czasach formowania się TB (np. Targum Szeni ad Est 1:3; Koran 27:43). Może to też być eufemizm na genitalia Asmodeusza - pytanie tylko, czy mógłby współżyć, mając na nich skarpetę.

${ }^{39}$ Fraza przed strachem $w$ [każda] noc bywa interpretowana jako odnosząca się do demona czyhającego na nowożeńców (Köckert 1999, 329-331; Malul 1999, 851-854).

${ }^{40} \mathrm{Z}$ ontologią tagów tematycznych stosowanych w EvT można zapoznać się na stronie projektu (Elyonim veTachtonim b.d.). 
cechy organizmów żywych. Jakkolwiek rzeczony ustęp nie przedstawia systematycznego ich opisu, to jednak zawarte w nim informacje pozwalają wnioskować o całej sieci innych właściwości tychże. Przykładowo, skoro demony mogą być płci męskiej bądź żeńskiej, to najprawdopodobniej posiadają więcej cech dymorficznych zarówno anatomicznych jak i funkcjonalnych. Tendencję tę zdaje się zresztą potwierdzać sam Asmodeusz, który, gdy tylko udaje mu się podszyć pod Salomona, ochoczo oddaje się uciechom cielesnym w królewskim haremie ${ }^{41}$.

Istoty nadprzyrodzone są też więc jak najbardziej materialne. Demony dają się spętać, nawet jeśli wymaga to zastosowania jakichś szczególnych artefaktów, Asmodeusz może wznieść się do nieba, ale potrzebuje do tego skrzydeł, zaś szamir jest w stanie ciąć skałę. Ta ich materialność łączy się ze swoistym terytorializmem. Wspomniane już 300 gatunków szedim zamieszkuje miejscowość Szichin, demon Asmodeusz rezyduje na „pewnej górze”, a szamir przebywa przez większość czasu u księcia morza ${ }^{42}$. Wreszcie materialność wiąże się z ich procesami fizjologicznymi. Asmodeusz musiał zabezpieczyć sobie zapasy wody a gdy przyszło mu napić się wina, odurzył się nim i zapadł w sen. Można zatem wnioskować, że skoro demon pije wino i wodę, to pewnie może też jeść - a skoro tak to i zapewne nieobce mu są inne potrzeby i procesy fizjologiczne.

Wreszcie istoty nadprzyrodzone tutaj zaprezentowane posiadają umysły z wszystkimi tego konsekwencjami. Demony dysponują jakąś wiedzą, ale nie jest ona kompletna, dzięcioł jest związany przysięgą u księcia morza i gdy nie jest w stanie jej dopełnić, decyduje się na samobójstwo, niebiańscy aniołowie formułują sądy moralne, zaś Asmodeusz zdaje się mieć swoje preferencje erotyczne. W oczy rzucają się szczególnie możliwości intelektualne tego ostatniego: zna i cytuje fragmenty BH stosownie do okoliczności, posiada praktyczną wiedzę medyczną i wie dużo na temat psychologii ludzkich dążeń - prawdopodobnie nie bez znaczenia jest w tym kontekście bogate curriculum akademickie demona studiującego na ziemskich i niebiańskich uczelniach. Oprócz tego, istoty nadprzyrodzone posiadają też swoją wewnętrzną hierarchię, jakkolwiek jest ona dość niesprecyzowana: Asmodeusz jest opisany jako król wszystkich demonów a książę morza dysponuje władzą nad

${ }^{41} \mathrm{~TB}$ zawiera tradycje o wężu edeńskim współżyjącym z Ewą (m.in. Szabbat 145b-146a; Jewamot 103b; Awoda zara 22b), o Adamie płodzącym demony (Eruwin 18b) czy o Lilit chwytającej nocą mężczyzn śpiących samotnie (Szabbat 151b).

${ }^{42} \mathrm{Na}$ ten problem terytorializmu demonów ale w Pesachim 109b-112a uwagę zwraca również S. A. Ronis (Ronis 2015, 109, 127-128). 
szamirem. Wreszcie to właśnie hierarchia jest głównym tematem rozmowy Salomona i Asmodeusza w jednej z końcowych sekcji rzeczonej opowieści ${ }^{43}$.

Wszystko to sprawia, że między ludźmi a istotami nadprzyrodzonymi tworzą się skomplikowane relacje a z grubsza można je podzielić na współpracę i antagonizm. Salomon musi posłużyć się podstępem, żeby wydobyć od demonów pewne informacje, a Asmodeusz, jakkolwiek przez pewien czas wydaje się kooperować z królem dając mu porady medyczne, to jednak na koniec wymyka się spod kontroli i działa na jego niekorzyść. W narracji pojawiają się też istoty, które pozostają do pewnego stopnia poza tymi relacjami: książę morza, dzięcioł czy wreszcie sam szamir nie wchodzą w jakieś głębsze interakcje $\mathrm{z}$ bohaterami ludzkimi w analizowanym ustępie. Podsumowując, tak zaprezentowane w tekście istoty nadprzyrodzone dobrze wpisują się w kategorie opracowane na gruncie kognitywnych teorii religii (zob. np. McCauley 2016, 466-471), co z kolei otwiera drogę bardziej szczegółowemu opisowi w perspektywie zarówno jakościowej jak ilościowej.

Ostatnią kwestią, która rzuca się w oczy, jest nieobecność boga. Owszem, Salomon buduje mu świątynię a jego imię wzmiankowane jest na królewskich artefaktach apotropaicznych, niezbędnych do kontrolowania Asmodeusza, jednak on sam jest nieobecny. Z lektury można więc wywnioskować, że ludzie i istoty nadprzyrodzone są pozostawieni sami sobie, bez jakiejkolwiek wyższej instancji. Wrażenie to potęguje zachowanie Asmodeusza, który wielokrotnie dostrzega jałowość ludzkich starań: pan młody umrze i zostawi wdowę „uwięzioną” w obowiązku lewiratu, pewien mężczyzna zostawi po sobie świetnie uszyte buty a Salomonowi, potężnemu królowi, zostaną ostatecznie cztery łokcie jego grobu. Trudno nie odnieść wrażenia, że autorzy tej opowieści chcieli w usta Asmodeusza włożyć zawołanie Salomona-Koheleta: jałowość, wszystko to jałowość! Taki oto pożytek ma człowiek z całej swojej pracy pod stońcem (Koh 1:2-3).

${ }^{43} \mathrm{~W}$ kwestii hierarchii ludzi i istot nadprzyrodzonych często przywoływanym ustępem jest ten pochodzący z traktatu Chagiga 16a, w którym porównuje się ze sobą ludzi, aniołów i demony. 


\section{Bibliografia}

\section{Teksty źródłowe}

Elliger, Karl i Rudolph Wilhelm, red. 1977. Biblia Hebraica Stuttgartensia. Stuttgart: Deutsche Bibelgesellschaft.

Rodkinson, Michael L., tłum. 1916. The Babylonian Talmud. Boston: Talmud Society.

The Soncino Babylonian Talmud. 2001. Chicago: Davka Corp. [CD-ROM] The William Davidson Talmud. 2017. Koren Publishers.

\section{Opracowania}

Friedman, Michał, tłum. 2005. Agady talmudyczne: ludowe opowieści, baśnie, legendy, przypowieści, aforyzmy i przystowia wybrane z Talmudu, Wrocław: Wydawnictwo Dolnośląskie. [wydanie elektroniczne: Fundacja Nowoczesna Polska].

Avi-Yonah, Michael. 2007. „Shihin”. W Encyclopedia fudaica, zredagowane przez Fred Skolnik i Michael Berenbaum. Vol. 18. Detroit: Thomson Gale, s. 476.

Bacher, Wilhelm i Ludwig Blau. B.d. „Shamir”. W JewishEncyclopedia.com. Dostęp: 01.01.2020.

Brown, Francis, S.R. Driver, Charles A. Briggs i in., red. 1907. The Brown, Driver, Briggs Hebrew and English Lexicon: with an Appendix Containing the Biblical Aramaic: Coded with the Numbering System from Strong's Exhaustive Concordance of the Bible. Oxford: Clarendon Press.

Butler, Alison. 2011. Victorian Occultism and the Making of Modern Magic: Invoking Tradition. London - New York: Palgrave Macmillan.

Elyonim veTachtonim. B.d. Dostęp: 01.01.2020.

Friedländer, Michael. 1889. „The Age and Authorship of Ecclesiastes”. The Jewish Quarterly Review 4/1889: 359-375.

Frim, Daniel J. 2015. "And It Was in the Dwelling of Rabbi Joshua bar Perahiah...": Notes on the Anti-Demonic Get in the Jewish Babylonian Aramaic Incantation Bowls". The Review of Rabbinic Fudaism 18/2015: 192-226.

Harris, R Laird, Gleason L. Archer i Bruce K. Waltke, red. 1980. Theological Wordbook of the Old Testament. Chicago: The Moody Bible Institute. 
Holladay, William L. 2000. A Concise Hebrew and Aramaic Lexicon of the Old Testament. Leiden Boston Koln: Brill.

Hutter, Manfred. 1999. „Asmodeus”. W Dictionary of Deities and Demons in the Bible [dalej: DDD], zredagowany przez Karel van der Toorn, Bob Becking i Pieter Willem van der Horst, 106-108. Leiden - Boston: Brill.

Jastrow, Marcus. 1903. A Dictionary of the Targumim, the Talmud Babli and Yerushalmi, and the Midrashic Literature. London: Luzac\& Co.

Klein, Ernest. 1987. A Comprehensive Etymological Dictionary Of The Hebrew Language. Jerusalem: Carta.

Kohler, Kaufmann i Louis Ginzberg. B.d. „Asmodeus, or Ashmedai”. W JewishEncyclopedia.com. Dostęp: 01.01.2020.

Kosior, Wojciech. 2017. „Elyonim veTachtonim. Some Methodological Considerations on the Electronic Database of Angels, Demons and Ghosts in Early Rabbinic Literature". The Polish fournal of the Arts and Culture. New Series 1/2017: 89-112.

Köckert, Matthias. 1999. „Fear of Isaac”. W Dictionary of Deities and Demons in the Bible, K. van der Toorn, B. Becking et al. (red.), $2^{\text {nd }}$ edition, [DDD], 329-331.

Malul, Meir. 1999. „Terror of the night”. W DDD, 851-854.

McCauley, Robert. 2016. „Cognitive and Evolutionary Approaches to Religion”. W The Blackwell Companion to Naturalism, zredagowane przez Kelly James Clark, 462-48o. Chichester: John Wiley \& Sons.

Melamed, Ezra Zion. 2005. Aramaic-Hebrew-English Dictionary of the Babylonian Talmud. Jerusalem: The Samuel and Odette Levy Foundation.

Montgomery, James A. 1913. Aramaic Incantation Texts from Nippur. Philadelphia: University Museum.

Ronis, Sara A. 2015. "Do Not Go Out Alone at Night": Law and Demonic Discourse in the Babylonian Talmud. Yale University: praca doktorska.

Satlow, Michael L. 2018. Jewish Marriage in Antiquity. Princeton - Oxford: Princeton University Press.

Sefaria. B.d. „The William Davidson Talmud”. Dostęp: 01.01.2020.

Stave, Erik. B.d. „Æshma (Asmodeus, Ashmedai)”. W JewishEncyclopedia.com. Dostęp: 01.01.2020.

Steinsaltz, Adin. 1996. The Talmud. The Steinsaltz Edition. A Reference Guide. New York: Random House.

The Friedberg Jewish Manuscript Society. B.d. Dostęp: 01.01.2020. 


\title{
Abstract, keywords, about the author
}

\begin{abstract}
Tractate Gittin $68 \mathrm{a}-\mathrm{b}$ contains a unique rabbinic story about the adventures of king Solomon and demon Asmodeus. The king wishes to build the Jerusalem temple, but in order to do so he needs the support of the demon. The latter helps the king, but the price Solomon has to pay afterwards turns out to be very high and for the rest of his days the king sleeps surrounded by his armed guard in fear of the return of Asmodeus. Despite the complexity and richness of this tale, it has not yet been translated into Polish. What is more, due to the vividness of its protagonists it can exemplify the nuances of the world of the supernatural entities. The present study has therefore two main purposes: (1) the presentation of the Polish translation of the story of Solomon and Asmodeus present in Gittin 68a-b; and (2) the analysis of the said story using the categories of the Elyonim veTachtonim project, which aims at the creation of a complete database of the supernatural entities in the early rabbinic literature.
\end{abstract}

Keywords: Babylonian Talmud, demonology, Asmodeus, Salomon

Wojciech Kosion, a graduate of Psychology, Religious Studies and Jewish Studies, adjunct researcher at the Centre for Comparative Studies of Civilisations at the Jagiellonian University. His research involves the angelology and demonology in the Hebrew Bible and the early rabbinic literature. He is currently working on the Elyonim veTachtonim project - an online inventory of supernatural entities in the Babylonian Talmud (https://elyonimvetachtonim.project.uj.edu.pl/).

E-MAIL: wojciech.kosior@uj.edu.pl 